\title{
Buried active faults in the Zafferana Etnea territory (south-eastern flank of Mt. Etna): geometry and kinematics by earthquake relocation and focal mechanisms
}

\author{
Salvatore Alparone, Salvatore D'Amico, Salvatore Gambino*, Vincenza Maiolino
}

Istituto Nazionale di Geofisica e Vulcanologia, Sezione di Catania, Osservatorio Etneo, Catania, Italy

\author{
Article history \\ Received May 29, 2012; accepted February 22, 2013. \\ Subject classification: \\ Seismic swarm, Waveform correlation, Precise relocation, Fault-plane geometry, Earthquake faults: properties and evolution.
}

\begin{abstract}
We relocated seismicity that occurred from 2000 to 2005 inside a sector of Mt. Etna, comprising the town of Zafferana Etnea, using the double-difference technique. This approach revealed some spatial clusters of events at depths of $3.0 \mathrm{~km}$ to $5.5 \mathrm{~km}$ b.s.l., which suggested NE-SW-oriented and NNW-SSE-oriented active structures located west and north-west with respect to Zafferana Etnea. We also calculated 64 fault plane solutions, and azimuth and dip distributions of maximum compression $P$ axes. The data include eight events with magnitudes between 3.1 and 3.7 that caused damage to Zafferana Etnea. This approach has allowed the definition of the geometry of structures that show no surface evidence, but are potentially hazardous for this territory. These faults might be linked to the regional tectonics, although they were activated by stress changes related to a general pressurizing of the Mt. Etna magma system between 2000 and 2005.
\end{abstract}

\section{Introduction}

Mapping active fault patterns is important in local tectonic studies, and is crucial for the forecasting of seismic activity and eventual scenarios [Azzaro et al. 2013], and for improving our knowledge of potential risks to inhabitants. Using high-precision, earthquake-location techniques together with focal mechanisms, it is possible to produce clear images of active faults and their kinematics [e.g., Lipptsich et al. 2005, Gambino et al. 2012].

Mt. Etna, and in particular its eastern flank, is affected by local seismicity that might cause considerable damage despite its moderate magnitude [Azzaro 2004]. We considered a roughly $32 \mathrm{~km}^{2}$ sector of the Mt. Etna eastern flank, which comprises Zafferana Etnea (550 $\mathrm{m}$ a.s.1.), a town of roughly 9,000 inhabitants. As reported in the Macroseismic Catalogue of Mt. Etna [CMTE Working Group 2008], over the last 180 years, Zafferana Etnea has been affected by more than 140 seismic events with epicentral macroseismic intensity $\mathrm{I}_{0} \geq \mathrm{V}$ on the European Macroseismic Scale (EMS) [Grünthal 1998] that were located on the eastern and southern flanks of Mt. Etna. Forty-four of these events with epicentral intensities $\mathrm{I}_{0}$ between V EMS and VII EMS are located inside the analyzed sector. Macroseismic and tectonic studies have associated the strongest of these seismic events to the NNW-SSE continuance of the Santa Tecla Fault [Azzaro 2004], which is considered to be a buried fault, and is in the study area.

With respect to the overall volcanic seismicity, the peculiar feature of the eastern flank is the small foci depth: most of the earthquakes have been shallower than $6 \mathrm{~km}$ to 7 $\mathrm{km}$, and the magnitudes of the events seldom exceed 4.0. Nevertheless, despite their low-energy releases, they can produce destructive effects in a very narrow macroseismic area (epicentral macroseismic intensity $\mathrm{I}_{0}$ up to IX EMS), which can often be accompanied by co-seismic surface fracturing [Azzaro 2004].

In the 2000 to 2005 period, there was a marked increase in the seismicity in this analyzed area, which was mainly restricted to the Mt. Etna eastern flank [Allard et al. 2006], and which comprised about 3,000 events ( 65 with $\mathrm{Md} \geq 3.0$ ). These included eight events with $3.1 \leq \mathrm{Md} \leq 3.7$ that were located close to Zafferana Etnea (Table 1), which caused some damage [Azzaro et al. 2002, 2006b]. This period was characterized by three flank eruptions that occurred in JulyAugust 2001, October 2002-January 2003, and September 2004-March 2005, and therefore by the general pressurizing of the volcanic system.

Walter at al. [2005] reported that placing a pressurizing source at $4 \mathrm{~km}$ to $6 \mathrm{~km}$ b.s.l. tends to encourage models to reproduce faulting below $4 \mathrm{~km}$ b.s.l. on the eastern side of this volcano. Most of the previous focal mechanism studies of Mt. Etna that were carried out in the 2000 to 2005 period highlighted how the seismicity was caused by the pressurizing of the local volcanic system, due to intruding magma [e.g., Patanè et al. 2003, Barberi et al. 2004, Gambino 2004, Alparone et al. 2011].

In the present study, we applied the double-difference relocation technique [Waldhauser and Ellsworth 2000] to the 


\begin{tabular}{|c|c|c|c|c|c|c|c|c|c|c|c|}
\hline $\mathbf{N}^{\circ}$ & Year & Month & Day & Hour & Minute & Second & $\begin{array}{l}\text { Latitude } \\
\left({ }^{\circ} \mathrm{N}\right)\end{array}$ & $\begin{array}{c}\text { Longitude } \\
\left({ }^{\circ} \mathrm{E}\right)\end{array}$ & $\begin{array}{l}\text { Depth } \\
(\mathrm{km})\end{array}$ & Md & $\mathbf{I}_{0}$ \\
\hline 1 & 2002 & 11 & 24 & 6 & 59 & 58.99 & 15.0814 & 37.6872 & 5.94 & 3.7 & $5-6$ \\
\hline 2 & 2001 & 1 & 9 & 2 & 51 & 58.48 & 15.0717 & 37.7035 & 5.19 & 3.5 & 6 \\
\hline 3 & 2004 & 7 & 22 & 2 & 11 & 27.45 & 15.0782 & 37.7039 & 5.30 & 3.4 & 6 \\
\hline 4 & 2001 & 8 & 20 & 22 & 44 & 59.22 & 15.0775 & 37.7133 & 4.85 & 3.3 & 5 \\
\hline $3 a$ & 2004 & 7 & 22 & 2 & 8 & 52.69 & 15.0762 & 37.7037 & 6.04 & 3.3 & - \\
\hline $2 a$ & 2001 & 1 & 9 & 4 & 31 & 39.45 & 15.0737 & 37.7035 & 5.45 & 3.1 & - \\
\hline $3 b$ & 2004 & 7 & 22 & 2 & 12 & 30.76 & 15.0805 & 37.7044 & 6.75 & 3.1 & - \\
\hline 5 & 2005 & 10 & 21 & 22 & 13 & 00.32 & 15.0688 & 37.6983 & 5.78 & 3.1 & 5 \\
\hline
\end{tabular}

Table 1. Locations, duration magnitudes and macroseismic intensities for the main eight earthquakes recorded during the 2000 to 2005 period in the study area. Events 2 and 2a also belong to the same swarm as 3, 3a and 3b.

2000 to 2005 seismicity inside the area considered, starting from an initial dataset of 461 events, and we calculated 64 fault-plane solutions. All of these elements helped in the identification of several preferential alignments, which indicate the geometry and dynamics of the structures acting close to Zafferana Etnea that might cause further damage.

\section{Tectonic setting}

The geodynamic framework of Mt. Etna is characterized by a compressive stress regime, which is trending roughly N-S, due to the Eurasia-Africa plate collision, and an extensional regime which is trending roughly E-W.

Two main structural systems that are NNW-SSE and NE-SW oriented can be readily recognized in the Mt. Etna area [Lo Giudice et al. 1982]. The NNW-SSE structural trend is well-represented by the Timpe Fault System of the southeastern flank of the Etna volcano (Figure 1). This structural system represents the Sicilian on-shore continuation of the Malta Escarpment, the major NNW-SSE crustal-scale fault that separates the continental African platform from the oceanic Ionian Basin, and which extending from Malta Island to the Tyrrhenian Sea (Figure 1). The Santa Tecla is a fault that is part of the Timpe System in the area investigated. With little surface evidence, the NE-SW structure extends from south Calabria and the Straits of Messina, to Mt. Etna. The fault systems of Ripe Della Naca, Ragalna, together with minor faults that are located near Fiumefreddo and Praiola Bay, represent the possible southernmost development of the Messina-Fiumefreddo line (Figure 1) [Lanzafame et al. 1994, Monaco et al. 1997, Azzaro 1999].

However, the tectonic setting of Mt. Etna is linked not only to regional tectonics, but also to local processes, such as the gravitational spreading of the eastern and southern flanks of the volcano [e.g., Borgia et al. 1992, Solaro et al. 2010] and dyke-induced rifting. The complex interactions between regional and local processes causes the frequent seismic activity on Mt. Etna. In particular, the activity on the upper sector of the volcano is generally linked to magma dynamics, while on the low eastern flank, it is mainly linked to regional tectonics [De Guidi et al. 2012, and references therein].

\section{Historical seismic background}

In the past, eastern Sicily has suffered major destruction due to large but rare crustal regional events with moment magnitudes MW between 6.6 and 7.4. The volcanic district of Mt. Etna, and in particular its eastern flank, is in addition affected by more frequent, but less powerful, local seismicity [Azzaro 2004]. Although of moderate magnitudes (according to Azzaro et al. [2011], the maximum macroseismic magnitude has been 5.2), these earthquakes can also prove to be destructive (IX-X EMS) because of the very shallow foci (0.5$2.0 \mathrm{~km}$ ) and the spectral characteristics of the seismic source [Giampiccolo et al. 2007, Milana et al. 2008].

Since the $19^{\text {th }}$ century, volcanic and seismic activity of Mt. Etna has been regularly reported. For this reason it has been possible to compile a huge and qualitatively homogeneous catalog of macroseismic data. The Macroseismic Catalogue of Mount Etna Earthquakes from 1832 to 2008 [CMTE Working Group 2008] contains both epicentral parameters defined according to standard procedures, as well as intensities in EMS [Grünthal 1998]. The main features of the earthquakes in this volcanic district are: (i) strong attenuation of seismic energy in an orthogonal direction to the fault plane, which produces damage that extends along narrow zones (1-5 km long, up to $1 \mathrm{~km}$ wide) around the seismogenic source [Azzaro et al. 2006a]; and (ii) co-seismic surfacefaulting effects have been reported in detail in historical accounts for the major seismic events. For these reasons, earthquakes can be located and often associated to individual tectonic features.

Despite the spatial incompleteness from the uninhabited sectors of the Etna volcano (e.g., the summit area, the western and northern flanks), the distribution of long-term seismicity shows that most events are located on the eastern flank of the Etna volcano and are related to the activity of 


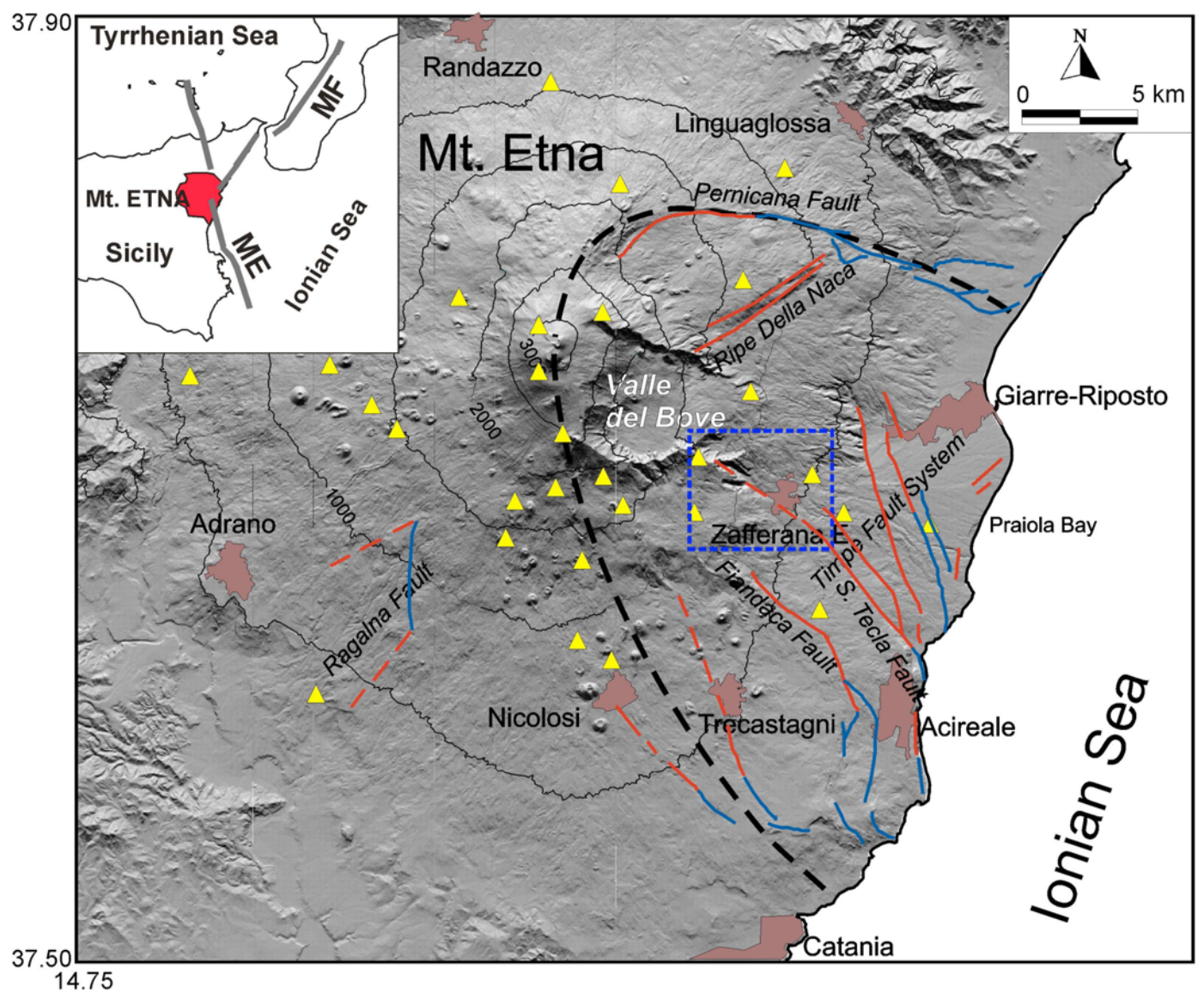

Figure 1. Surface faults map of Mt. Etna (modified from Azzaro et al. [2012]). Black dashed line, sliding sector; blue dashed rectangle, study area; triangles, permanent seismic stations. Inset map: main regional fault systems. MF, Messina-Fiumefreddo Line; ME, Malta Escarpment.

the Timpe Fault System (the S. Tecla, S. Leonardello and Moscarello Faults). Figure 2 shows the macroseismic epicenters of 231 earthquakes that occurred on the south-eastern flank of Mt. Etna from 1832 to 2005, with epicentral intensities $\mathrm{I}_{0} \geq \mathrm{V}$ EMS, $\mathrm{M} \geq 2.6$ [Azzaro et al. 2011]. According to class Q of CMTE [CMTE Working Group 2008], 90 events $(\mathrm{Q}=1)$, which mainly represent the strongest ones, are wellconstrained and have been related to a specific fault; 70 events $(\mathrm{Q}=2)$ are not related to any specific structure, although they were well constrained (errors in location of between $1 \mathrm{~km}$ and $3 \mathrm{~km}$ ). The gray circles in Figure 2 represent events that were related to the $S$. Tecla Fault, while the white circles indicate earthquakes related to other non-related seismogenic sources.

Given that the macroseismic epicenter is calculated as the barycenter of the data points with intensity $\mathrm{I}=\mathrm{I}_{0}, \mathrm{I}_{0}-1$, the macroseismic location and the instrumental location might be different, although the uncertainties are generally confined to within $3 \mathrm{~km}$ [Azzaro et al. 2000]. In particular, in the study area (Figure 2, box), that is sited at the north-western end of the $S$. Tecla Fault, most of the earthquakes are located on its eastern side and are related to the fault. The most powerful events in the Zafferana Etnea territory $\left(\mathrm{I}_{0} \geq\right.$ VII EMS, $M \geq 3.8$ ) occurred in 1883 and 1984. During the 20002005 period, this territory was affected by eight events (Table $1)$, five of which showed $I_{0} \geq \operatorname{VEMS~}(3.1 \leq \mathrm{Md} \leq 3.7)$.

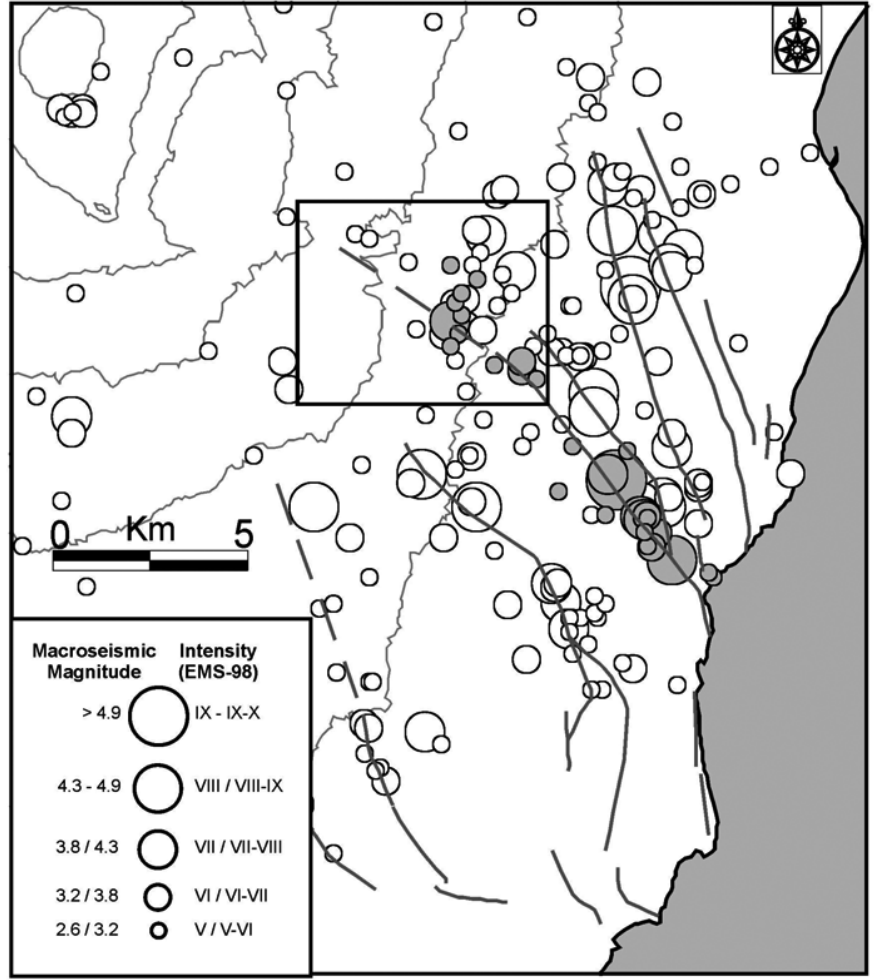

Figure 2. Macroseismic epicenters of earthquakes with epicentral intensities $I_{0} \geq V$ EMS (macroseismic $M \geq 2.6$ ) that occurred from 1832 to 2005 on the south-eastern flank of Mt. Etna. Data from the Catalogo Macrosismico dei Terremoti Etnei dal 1832 al 2008 [CMTE Working Group 2008]. Gray circles, earthquakes related to the S. Tecla Fault; box, study area. 


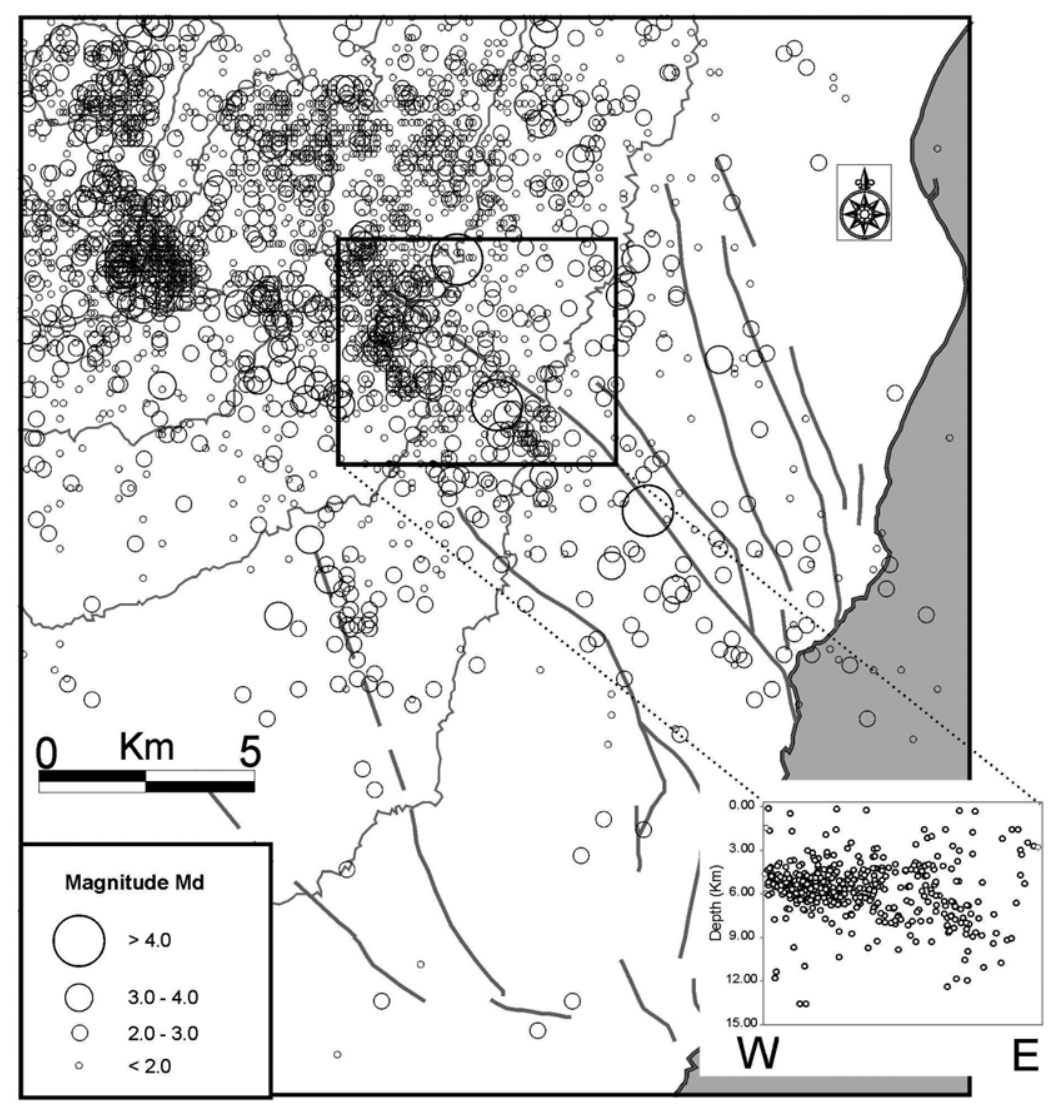

Figure 3. Map of the 2000 to 2005 earthquakes located for surveillance purposes from instrumental data [Gruppo Analisi Dati Sismici 2011]. Box, study area. Inset: EW cross-section of the seismicity of the study area.

\section{The network}

The Mt. Etna seismic activity is recorded by the Istituto Nazionale di Geofisica e Vulcanologia (INGV) permanent local seismic network. In most of the investigated period, the seismic network consisted of 30 seismic stations (Figure 1), of which 15 were equipped with vertical geophones, and 15 with three-component geophones (11 of which had broadband high-dynamics sensors). All of the data were transmitted in real time to the data acquisition center in Catania, through radio and satellite links.

Although during the study period the arrangements of the seismic network that was operating on the Etna volcano underwent some changes in terms of the number of stations, the geometric configuration in the area investigated was always useful for the detection of events and for the conducting of investigations. The distance between the stations used in this area varies from $2 \mathrm{~km}$ to $7 \mathrm{~km}$.

\section{Data and earthquake relocation}

We considered an initial dataset of 461 earthquakes with duration magnitudes $\mathrm{Md} \geq 0.8$, that occurred between 2000 to 2005 within a sector of the south-eastern flank of the Etna volcano, which was delimited by the following coordinates: $15.060^{\circ} \mathrm{E}-37.675^{\circ} \mathrm{N}$ and $15.130^{\circ} \mathrm{E}-37.720^{\circ} \mathrm{N}$ (about $32 \mathrm{~km}^{2}$; Figure 3, box area). About $20 \%$ of these events were $\mathrm{Md} \geq 2.5$, with a maximum magnitude of 4.4 .

First, the earthquakes were located (Figure 3) [Gruppo
Analisi Dati Sismici 2011] using the hypoellipse algorithm [Lahr 1999] and one-dimensional crustal velocity model proposed for the Etna area by Hirn et al. [1991], and subsequently modified by Patanè et al. [1994]. The spatial distribution of the epicenters shows an interesting feature. The events are mainly grouped west of Zafferana Etnea, while they are more sparse in the eastern area (Figure 3). The hypocenters mainly ranged between depths of $4 \mathrm{~km}$ and $7 \mathrm{~km}$ b.s.l.

We applied the double-difference earthquake algorithm of Waldhauser and Ellsworth [2000], using the HypoDD program [Waldhauser 2001]. The algorithm takes advantage of knowing that if the hypocentral separation between two earthquakes is small enough compared to the event-station distance and the scale length of the velocity heterogeneity, then the ray paths are similar along almost the entire length [Got et al. 1994]. Under this assumption, the differences in the travel-times for two earthquakes recorded at the same station can be attributed to differences in their hypocenter spatial separation. In this way, errors due to inaccurately modeled velocity structures are minimized without the use of station corrections. This technique has been used in several studies [e.g., Schaff et al 2002, Gambino et al. 2004, Lippitsch et al. 2005, Bonforte et al. 2009, Alparone et al. 2013], whereby it has produced sharp images of the fault structures under study.

During the computation, HypoDD performs a reduction in the data, because it groups the events into clusters of 
well-connected earthquakes and removes those that can be considered as outliers. The HypoDD solutions are not unique, but they depend on the parameters used. Earthquake relocation with HypoDD is a two-step process. The first step involves the analysis of the catalog phase data and/or waveform data, to derive travel-time differences for pairs of earthquakes. A screening of the data is necessary to optimize the linkage between the events and to minimize redundancy in the dataset. In the second step, the differential travel-time data from step one are used to determine the double-difference hypocenter locations.

In the first step, HypoDD searches catalog P-phase and $S$-phase data for event pairs with travel-time information at common stations, and subsamples these data to optimize the quality of the phase pairs and the connectivity between the events. Ideally, we seek a network of links between events so that there is a chain of pair-wise connected events from any one event to any other event, with the distance being as small as possible between connected events [Waldhauser 2001]. The program establishes such a network by building links from each event to a maximum of neighboring events within a search radius that we chose, of $1.0 \mathrm{~km}$. Therefore, we started with an initial data set of the 461 earthquakes that were obtained in the first selection; our final dataset is made up of the 93 more well-connected events that the HypoDD program split into two clusters (Figure 4, 1 and 2). The final dataset comprises the eight main shocks with $3.1 \leq \mathrm{Md} \leq 3.7$.

The results of these relocations show a mean hypocentral error of $0.12 \mathrm{~km}$ for the epicentral coordinates, and 0.15 $\mathrm{km}$ for the focal depth. The mean errors of the routine analytical locations for the same events, were $0.26 \mathrm{~km}$ and 0.32 $\mathrm{km}$, respectively. The mean root mean square decreased from $0.12 \mathrm{~s}$ in the initial dataset, to $0.08 \mathrm{~s}$ in the relocated catalog.

Figure 4 shows the epicentral map of the relocated earthquakes obtained with the HypoDD algorithm. The cluster 2 showed a NE-SW alignment, while the events that make up the larger cluster 1, show both NE-SW and NNWSSE alignments. In total, we recognized four NE-SW clusters (C1-C4), each comprising 10-15 events (Figure 4), and one NNW-SSE cluster (C5) made up of ca. 30 events.

The NE-SW clusters (Figure 4) appear to reveal four roughly parallel structures, no longer than $1.5 \mathrm{~km}$ each, with depths confined to between $3 \mathrm{~km}$ and $5 \mathrm{~km}$. The unique NNWSSE cluster (C5) is mainly clustered between $3 \mathrm{~km}$ and $4.5 \mathrm{~km}$.

\section{Focal mechanisms}

To better understand the kinematics within each cluster, we calculated the focal plane solutions for the earthquakes with a minimum of six P-polarities. In all, 83 focal-plane solutions of the 93 relocated earthquakes were computed using the FPFIT code of Reasenberg and Oppenheimer [1985].

The focal solutions are believed to be reliable enough to meet certain quality criteria: we discarded the solutions where
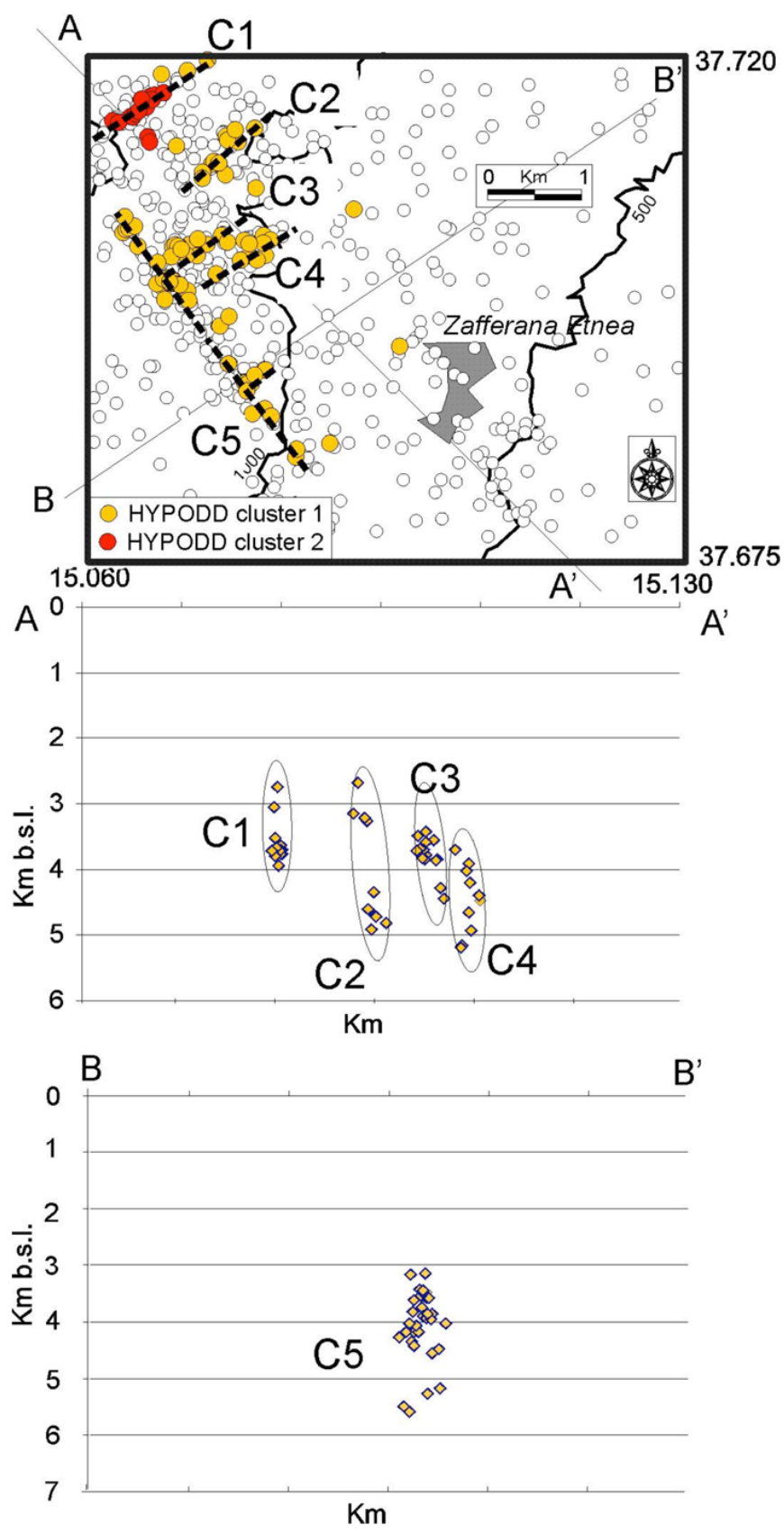

Figure 4. Map and oriented vertical cross-sections of the seismicity relocated using HypoDD. Thick dashed lines indicate the main structural features described in the text. Directions of the vertical cross sections are indicated in the maps by lines A-A' and B-B'. White circles, original locations.

their errors were associated with the dip direction and rake angle on shown values $>15^{\circ}$, and we privileged unique solutions. However, in the case of multiple solutions with the same kinematics, we chose the solutions with the smaller $\mathrm{P}$ and $\mathrm{T}$ axes cloud dispersion. Finally, the selected solutions have no more than $20 \%$ discrepancy in their polarity. Figure 5 shows the 64 focal solutions obtained with the associated clusters. Although the kinematics are all present, we observe a predominance of transcurrent mechanisms that are associated with a minor component of dip (Figure 5). The majority of the maximum compression $P$ axes $(65 \%)$ have an azimuth between $90^{\circ}$ and $135^{\circ}$ (Figure 6a), while the dip angles are concentrated between $20^{\circ}$ and $50^{\circ}(60 \%)$ (Figure $6 \mathrm{~b}$ ). The earthquakes be- 


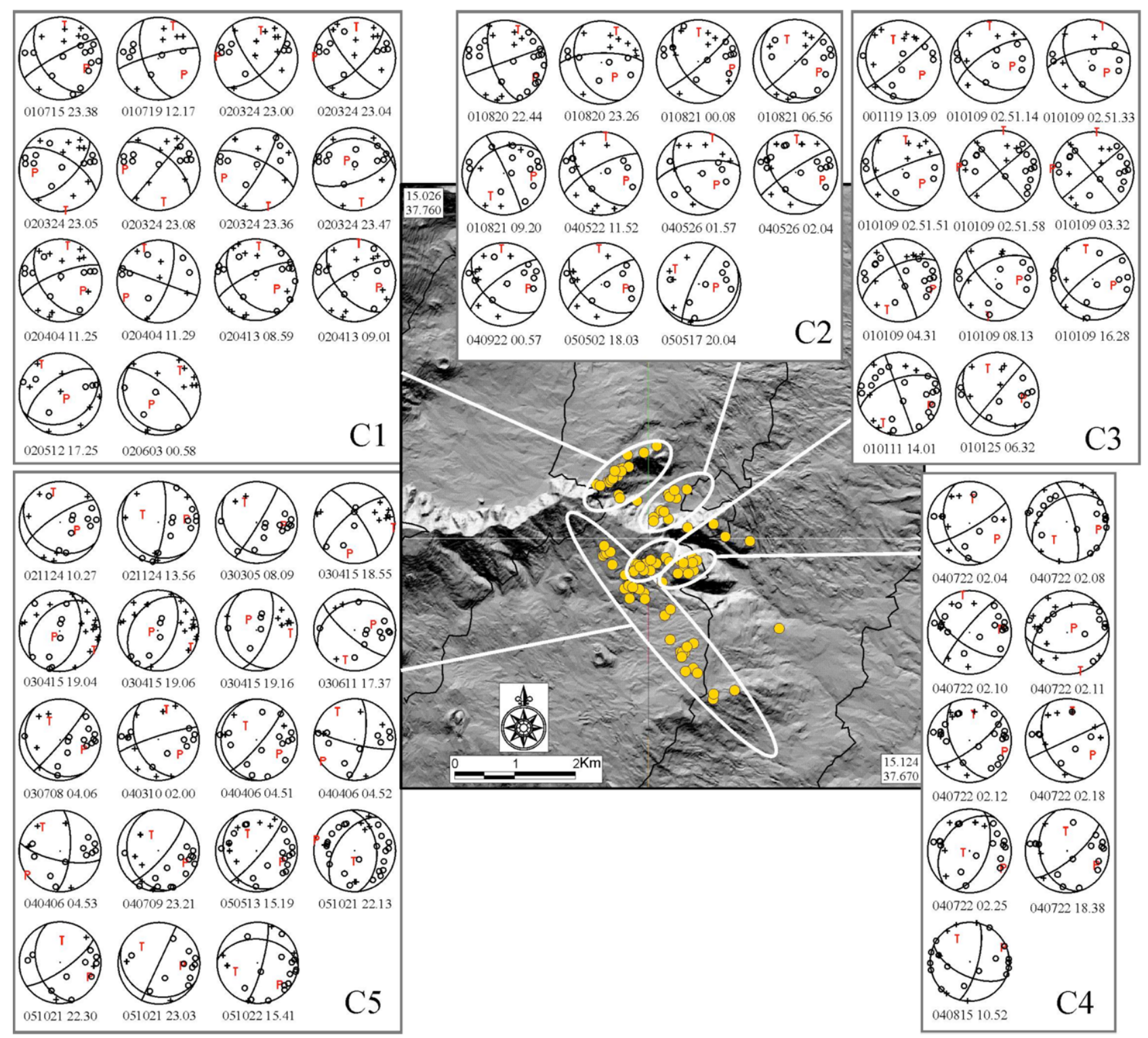

Figure 5. Focal mechanisms related to each recognized cluster.

longing to the NE-SW clusters show a dextral transcurrent kinematics type (more than $70 \%$ of the focal solutions), on planes that were oriented roughly NE-SW, which reflects the epicenter distribution. From the kinematics point of view, the NNW-SSE cluster, which includes many more earthquakes, shows some variability, including dip and transcurrent mechanisms with different focal planes (Figure 5).

\section{Discussion and conclusions}

Relocation of events located in a sector of Mt. Etna comprising the Zafferana Etnea territory was performed here, along with an analysis of the fault-plane solutions. The aim was to identify and map the active faults proximal to Zafferana Etnea, and to define their kinematics. This represents an extension to the analyses of Alparone and Gambino [2003], who examined August, 1995, and January, 2001, data for reconstruction through a cross-spectrum technique, a $1.0-\mathrm{km}$ long, NE-SW oriented active seismogenic structure located $2.0 \mathrm{~km}$ west of Zafferana Etnea (Figure 7, yellow diamonds).
We considered 461 events that were recorded in this area over the 2000 to 2005 period. The double-difference relocation results show that part of the seismicity is clustered along lineaments that define four NE-SW clusters (C1-C4) and one main NNW-SSE cluster (C5). The events that Alparone and Gambino [2003] relocated were inside the C3 cluster, and the results are very similar, even if they were obtained using a different relocation method. Earthquakes belonging to the NE-SW clusters have the most dextral transcurrent kinematics type (70\%) on planes oriented roughly NE-SW, and therefore these clusters (C1-C4) might represent buried active faults located north-west of Zafferana Etnea, at $3.0 \mathrm{~km}$ to $5.5 \mathrm{~km}$ in depth, with dextral transcurrent kinematics (Figure 7). These roughly parallel structures can be linked to the Messina-Fiumefreddo regional tectonic trend.

The NNW-SSE cluster (C5) shows some variability from the kinematics point of view. The $\mathrm{C} 5$ cluster appears to represent a buried structure with the same trend of some faults of the Timpe system, like Santa Tecla and Fiandaca, showing 

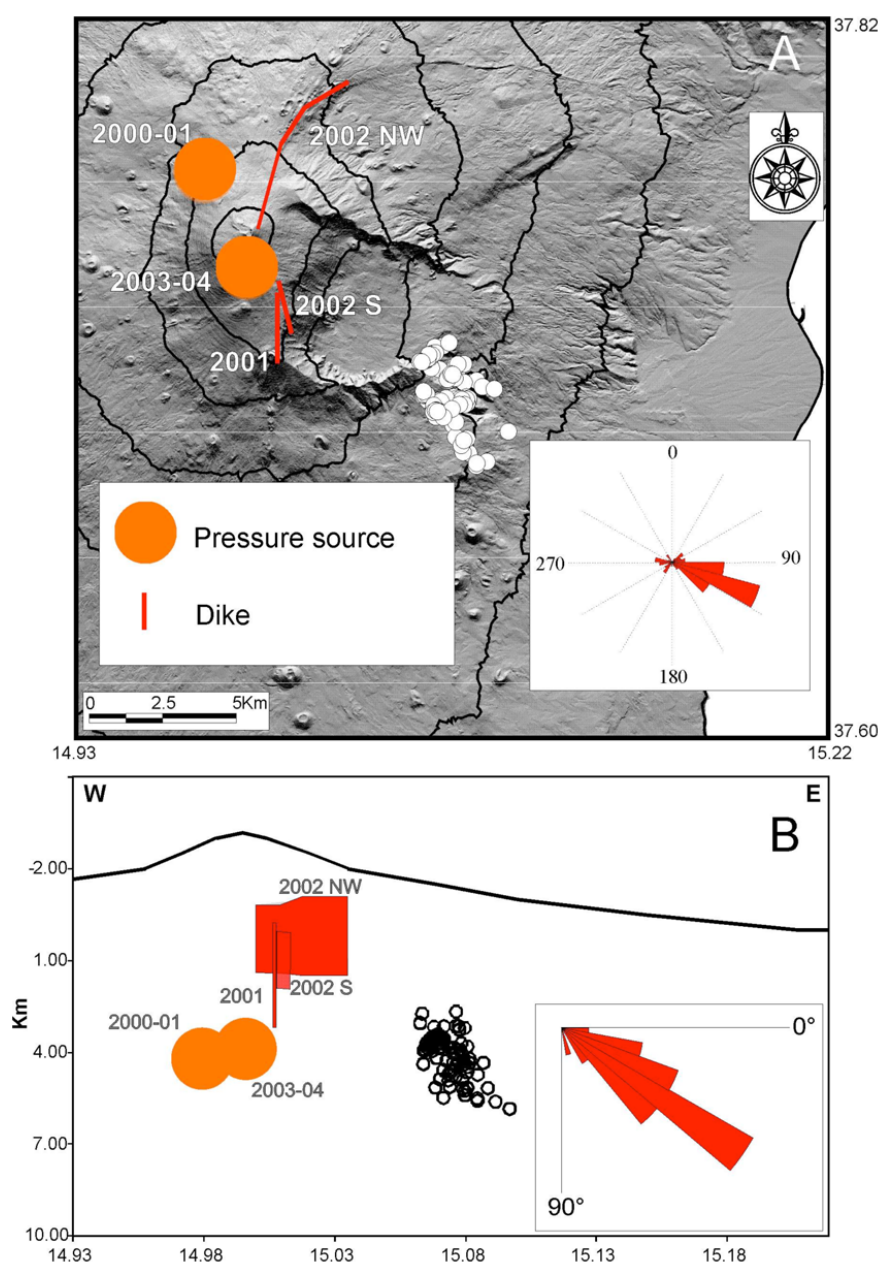

Figure 6. Map (A) and cross-section (B) showing the relocated events and the magmatic sources modeled using 2000 to 2005 ground-deformation data [Puglisi and Bonforte 2004, Aloisi et al. 2006, Bonaccorso et al. 2006]. Insets: azimuth distribution (top) and dip angle (bottom) of the axis of maximum compression $P$ referred to all of the relocated events.

its surface evidence in the south-east of this area. However, the variability of the focal mechanisms suggests a more complex structure, rather than one single fault (Figure 7).

On the whole, the seismicity shows a homogeneous azimuth distribution of the axis of maximum compression $\mathrm{P}$ around $\mathrm{N} 90-135^{\circ} \mathrm{E}$, with a dip angle of $20^{\circ}$ to $50^{\circ}$ (Figure 6). The direction and dip angles of the $\mathrm{P}$ axes match well with the seismicity position with respect to magma sources modeled by ground deformation for the 2000 to 2005 period (Figure 6), in particular for the dike intrusion sources of the south flank. This factor suggests that, during 2000 to 2005 , the faults close to Zafferana Etnea were activated by stress changes that were related to the pressurizing of the magma systems, as was also assessed by Alparone et al. [2011], in relation to the 2003 to 2004 seismicity located on the eastern flank at a depth of $3 \mathrm{~km}$ to $7 \mathrm{~km}$.

Finally, the relocated hypocenters of the strongest events (Table 1) that are reported in Figure 6, suggest how the recognized system of faults is made up of structures that can generate moderate energy releases that are potentially dangerous for the Zafferana Etnea area. The identified fault geometry

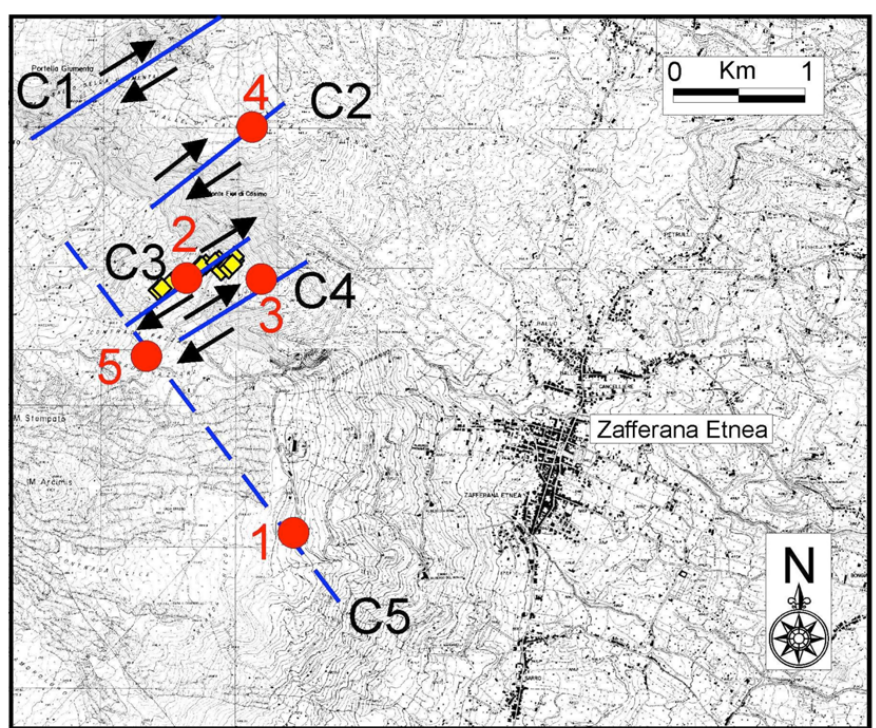

Figure 7. Recognized buried faults and kinematics. Red circles, locations of the most powerful events in the 2000 to 2005 period (see also Table 1); yellow diamonds, high-precision relocated events of Alparone and Gambino [2003].

and kinematics thus represent new local tectonic insights that will be helpful in potential risk scenario planning.

Acknowledgements. The authors thank the 'INGV-CT Gruppo Analisi Dati Sismici' for their help in the analyses of these earthquakes. The authors are also grateful to an anonymous referee and to the Editor in Chief, Edoardo Del Pezzo, for their constructive comments.

\section{References}

Allard, P., B. Behncke, S. D'Amico, M. Neri and S. Gambino (2006). Mount Etna 1993-2005: anatomy of an evolving eruptive cycle, Earth-Sci. Rev., 78, 85-114; doi:10.1016/j. earscirev.2006.04.002.

Alparone, S., and S. Gambino (2003). High precision locations of multiplets on south-eastern flank of Mt. Etna (Italy): reconstruction of fault plan geometry, Physics Earth Planet. Int., 135, 281-289.

Alparone, S., G. Barberi, A. Bonforte, V. Maiolino and A. Ursino (2011). Evidence of multiple strain fields beneath the eastern flank of Mt. Etna volcano (Sicily, Italy) deduced from seismic and geodetic data during 2003-2004, Bull. Volcanol., 73, 869-885; doi:10.1007/s00445-011-0456-1.

Alparone, S., O. Cocina, S. Gambino, A. Mostaccio, S. Spampinato, T. Tuvè and A. Ursino (2013). Seismological features of the Pernicana-Provenzana fault system and implications for the dynamics of northeastern flank of the volcano, J. Volcanol. Geotherm. Res., 251, 16-26; doi:10.1016/j.jvolgeores.2012.03.010.

Aloisi, M., A. Bonaccorso and S. Gambino (2006). Imaging composite dike propagation (Etna, 2002 case), J. Geophys. Res. 111, B06404; doi:10.1029/2005JB003908.

Azzaro, R. (1999). Earthquake surface faulting at Mount Etna volcano (Sicily) and implications for active tectonics, J. Geodynam., 28, 193-213. 
Azzaro, R., M.S. Barbano, B. Antichi and R. Rigano (2000). Macroseismic catalogue of Mt. Etna earthquakes from 1832 to 1998, Acta Vulcanol., 12, 3-36.

Azzaro, R., S. D'Amico, A. Mostaccio and L. Scarfi (2002). Terremoti con effetti macrosismici in Sicilia Orientale Calabria Meridionale nel periodo Gennaio 1999-Dicembre 2001, Quad. Geofis., 27, 1-59.

Azzaro, R. (2004). Seismicity and active tectonics in the Etna region: constraints for a seismotectonic model, In: Mt. Etna: volcano laboratory, A. Bonaccorso, S. Calvari, M. Coltelli, C. Del Negro and S. Falsaperla (eds.), American Geophysical Union, Geophysical monograph, 143, 205-220.

Azzaro, R., M.S. Barbano, S. D'Amico and T. Tuvè (2006a). The attenuation of seismic intensity in the Etna region and comparison with other Italian volcanic districts, Annals of Geophysics, 49 (4/5), 1003-1020.

Azzaro, R., S. D'Amico, A. Mostaccio, L. Scarfi and Y. Tuvè (2006b). Terremoti con effetti macrosismici in Sicilia Orientale - Calabria Meridionale nel periodo Gennaio 2002 Dicembre 2005, Quad. Geofis., 41, 1-60.

Azzaro, R., S. D'Amico and T. Tuvè (2011). Estimating the magnitude of historic earthquakes from macroseismic intensity data: new relationships for the volcanic region of Mount Etna (Italy), Seismol. Res. Lett., 82, 533-544.

Azzaro, R., S. Branca, K. Gwinner and M. Coltelli (2012). The volcano-tectonic map of Etna volcano, 1:100.000 scale: an integrated approach based on a morphotectonic analysis from high-resolution DEM constrained by geologic, active faulting and seismotectonic data, It. J. Geosci., 131, 153-170; doi:10.3301/IJG.2011.29.

Azzaro, R., S. D'Amico, R. Rotondi, T. Tuvè and G. Zonno (2013). Forecasting seismic scenarios on Etna volcano (Italy) through probabilistic intensity attenuation models: a Bayesian approach, J. Volcanol. Geotherm. Res., 251, 149-157.

Barberi, G., O. Cocina, V. Maiolino, C. Musumeci and E. Privitera (2004). Insight into Mt. Etna (Italy) kinematics during the 2002-2003 eruption as inferred from seismic stress and strain tensors, Geophys. Res. Lett., 31, L21614; doi:10.1029/2004GL020918.

Bonaccorso, A, A. Bonforte, F. Guglielmino, M. Palano and G. Puglisi (2006). Composite ground deformation pattern forerunning the 2004-2005 Mount Etna eruption, J. Geophys. Res., 111, B12207; doi:10.1029/2005JB004206.

Bonforte, A., S. Gambino and M. Neri (2009). Intrusion of eccentric dikes: the case of the 2001 eruption and its role in the dynamics of Mt. Etna volcano, Tectonophysics, 471, 78-86; doi:10.1016/j. tecto.2008.09.028.

Borgia, A., L. Ferrari and G. Pasquarè (1992). Importance of gravitational spreading in the tectonic evolution of Mt. Etna, Nature 357, 231-235; doi:10.1038/357231a0.

CMTE Working Group (2008). Catalogo Macrosismico dei Terremoti Etnei, 1832-2008, INGV, Catania, http:/ / www. ct.ingv.it/ufs/macro/.

De Guidi, G., S. Scudero and S. Gresta (2012). New insights into the local crust structure of Mt. Etna volcano from seismological and morphotectonic data, J. Volcanol. Geotherm. Res., 223-224, 83-92.

Gambino, S. (2004). Continuous dynamic response along a pre-existing structural discontinuity induced by the 2001 eruption at Mt Etna, Earth Planets Space, 56, 447-456.

Gambino, S., A. Mostaccio, D. Patanè, L. Scarfi and A. Ursino (2004). High-precision locations of the microseismicity preceding the 2002-2003 Mt. Etna eruption, Geophys. Res. Lett., 31, L18604; doi:10.1029/2004GL020499.

Gambino, S., V. Milluzzo, A. Scaltrito and L. Scarfi (2012). Relocation and focal mechanisms of earthquakes in the south-central sector of the Aeolian Archipelago: new structural and volcanological insights, Tectonophysics, 524-525, 108-115.

Giampiccolo, E., S. D'Amico, D. Patanè and S. Gresta (2007). Attenuation and source parameters of shallow microearthquakes at Mt. Etna volcano (Italy), Bull. Seismol. Soc. Am., 97, 184-197.

Got, J.L., J. Fréchet and F.W. Klein (1994). Deep fault plane geometry inferred from multiplet relative relocation beneath the south flank of Kilauea, J. Geophys. Res., 99, 15375-15386.

Grünthal, G., ed. (1998). European macroseismic scale 1998 (EMS-98). European Seismological Commission, Subcommission on Engineering Seismology, Working Group Macroseismic Scales. Conseil de l'Europe, Cahiers du Centre Européen de Géodynamique et de Séismologie, 15, Luxembourg, $99 \mathrm{pp}$.

Gruppo Analisi Dati Sismici (2011). Catalogo dei terremoti della Sicilia Orientale - Calabria Meridionale (1999-2011), INGV, Catania http: / / www.ct.ingv.it/ufs/analisti/ cata logolist.php.

Hirn, A., A. Nercessian, M. Sapin, F. Ferrucci and G. Wittlinger (1991). Seismic heterogeneity of Mt. Etna: structure and activity, Geophys. J. Int., 105, 139-153.

Lahr, J.C. (1999). Hypoellipse: a computer program for determining local earthquake hypocentral parameters, magnitude, and first motion pattern (Y2K compliant), U.S. Geological Survey, Open File Report, 99-23.

Lanzafame, G., M. Neri and D. Rust (1994). Active tectonics affecting the eastern flank of Mount Etna: structural interactions at a regional and local scale, In: Etna: 15 years on, P.J. Gravestock and W.J. Mc Guire (eds.), Cheltenham and Gloucester Special Publication, 25-33.

Lippitsch, R., R. White and H. Soosalu (2005). Precise hypocenter relocation of microearthquakes in a high-temperature geothermal field: the Torfajökull central volcano, Iceland, Geophys. J. Int., 160, 371-388.

Lo Giudice, E., G. Patanè, T. Rasà and R. Romano (1982). The structural framework of Mt. Etna, Mem. Soc. Geol. 
It., 23, 125-158.

Milana, G., A. Rovelli, A. De Sortis, G. Calderoni, G. Coco, M. Corrao and P. Marsan (2008). The role of long-period ground motions on magnitude and damage of volcanic earthquakes on Mt. Etna, Italy, Bull. Seismol. Soc. Am., 98, 2724-2738.

Monaco, C., P. Tapponnier, L. Tortorici and P.Y. Gillot (1997). Late Quaternary slip rates on the Acireale-Piedimonte normal faults and tectonic origin of Mt. Etna (Sicily), Earth Planet. Sci. Lett., 147, 125-139.

Patanè, G., A. Montalto, S. Imposa and S. Menza (1994). The role of regional tectonics, magma pressure and gravitational spreading in earthquakes of the eastern sector of Mt. Etna volcano (Italy), J. Volcanol. Geotherm. Res., 61, 253-266.

Patanè, D., E. Privitera, S. Gresta, S. Alparone, A. Akinci, G. Barberi, L. Chiaraluce, O. Cocina, S. D'Amico, P. De Gori, G. Di Grazia, S. Falsaperla, F. Ferrari, S. Gambino, E. Giampiccolo, H. Langer, V. Maiolino, M. Moretti, A. Mostaccio, C. Musumeci, D. Piccinini, D. Reitano, L. Scarfi, A. Ursino and L. Zuccarello (2003). Seismological constraints for the dyke emplacement of July-August 2001 lateral eruption at Mt. Etna Volcano, Italy, Annals of Geophysics, 46 (4), 599-608.

Puglisi, G., and A. Bonforte (2004) Dynamics of Mount Etna Volcano inferred from static and kinematic GPS measurements, J. Geophys. Res., 109, B11404; doi:10.1029/20 03JB002878

Reasenberg, P., and D. Oppenheimer (1985). FPFIT, FPPLOT and FPPAGE: FORTRAN computer programs for calculating and displaying fault plane solutions, U.S. Geological Survey, Open File Report, 85 / 739, 1-109.

Schaff, D.P., G.H.R. Bokelmann, F. Beroza, F. Waldhauser and W.L. Ellsworth (2002). High-resolution image of Calaveras Fault, California, seismicity, J. Geophys. Res., 107, B92186; doi:10.1029/2001JB000633.

Solaro, G., V. Acocella, S. Pepe, J. Ruch, M. Neri and E. Sansosti (2010). Anatomy of an unstable volcano from InSAR: multiple processes affecting flank instability at Mt. Etna, 1994-2008, J. Geophys. Res., 115, B10405; doi:10.1029/2009JB000820.

Waldhauser, F., and W.L. Ellsworth (2000). A double-difference earthquake location algorithm: method and application to the northern Hayward Fault, California, Bull. Seismol. Soc. Am., 90, 1353-1368.

Waldhauser, F. (2001). HypoDD: A computer program to compute double-difference earthquake locations, U.S. Geological Survey, Open File Report, 01/113, 1-25.

Walter, T.R., V. Acocella, M. Neri and F. Amelung (2005). Feedback processes between magmatic events and flank movement at Mount Etna (Italy) during the 2002-2003 eruption, J. Geophys. Res., 110, B10205; doi:10.1029/2005 jb003688.
${ }^{\star}$ Corresponding author: Salvatore Gambino, Istituto Nazionale di Geofisica e Vulcanologia, Sezione di Catania, Osservatorio Etneo, Catania, Italy; email: gambino@ct.ingv.it.

(C) 2013 by the Istituto Nazionale di Geofisica e Vulcanologia. All rights reserved. 